\title{
Case Report and Literature Review: COVID-19 and status \\ epilepticus in Dyke-Davidoff-Masson syndrome [version 1;
}

\section{peer review: 2 approved]}

\section{Lourdes de Fátima Ibañez Valdés (D1) Jerry Geroge1, Sibi Joseph1, Mohamed Alshmandi², Wendy Makaleni², Humberto Foyaca Sibat (iD1}

\footnotetext{
${ }^{1}$ Neurology Department, Walter Sisulu University/ Nelson Mandela Academic Hospital, Mthatha, Eastern Cape, 5100, South Africa 2Internal Medicine Department, Walter Sisulu University/Nelson Mandela Academic Hospital, Mthatha, Eastern Cape, 5100, South Africa
}

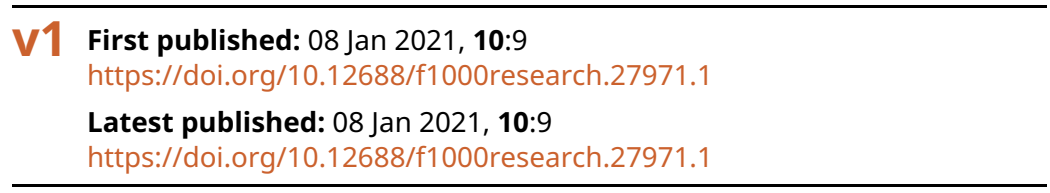

\section{Abstract}

Dyke-Davidoff-Masson syndrome (DMMS) is a non-inherited rare condition with a clinical constellation of hemiparesis/hemiplegia, facial asymmetry, intellectual disability, and epilepsy. The radiological features can be including unilateral cerebral atrophy, calvarial thickening, and hyper pneumatization of the paranasal sinuses. The condition can either be congenital or acquired. The presentation usually occurs during childhood or early adolescents, but there have been adult cases reported.

Here we report a 48-year-old male who was a known poorly controlled epileptic that contracted SARS-CoV-2 with subsequently developed status epilepticus and, when worked up, was shown to have features of DDMS. This case is unique as the patient had hemiatrophy and epilepsy but managed to lead a normal, physically demanding, and high functioning academic career and presented late in life. Perhaps only due to coronavirus disease 2019 (COVID-19) was this diagnosis picked up.

This report contains a case presenting atypical DDMS in status epilepticus and COVID -19 plus other complications. From our knowledge, this is the first case presenting these comorbidities reported to the medical literature.

\section{Keywords}

Covid-19, Dyke-Davidoff-Mason Syndrome, status epilepticus, hyperglycaemic hyperosmolar syndrome

\section{Open Peer Review}

Approval Status

1 2

version 1

08 Jan 2021

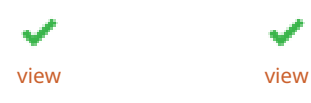

\section{Emilia Virginia Noormahomed,}

Universidade Eduardo Mondlane (UEM),

Maputo, Mozambique

2. Rizwana Shahid, Imam Abdulrahman Bin

Faisal University, Dammam, Saudi Arabia Any reports and responses or comments on the article can be found at the end of the article. 


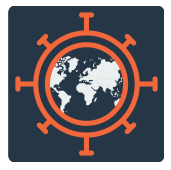

This article is included in the Emerging Diseases

and Outbreaks gateway.

collection.

\section{Corresponding author: Humberto Foyaca Sibat (humbertofoyacasibat@gmail.com)}

Author roles: Ibañez Valdés LdF: Conceptualization, Investigation, Methodology, Writing - Original Draft Preparation; Geroge J: Investigation, Writing - Original Draft Preparation; Joseph S: Investigation, Methodology; Alshmandi M: Conceptualization, Investigation; Makaleni W: Conceptualization, Investigation; Foyaca Sibat H: Conceptualization, Supervision, Writing - Review \& Editing Competing interests: No competing interests were disclosed.

Grant information: The author(s) declared that no grants were involved in supporting this work.

Copyright: @ 2021 Ibañez Valdés LdF et al. This is an open access article distributed under the terms of the Creative Commons Attribution License, which permits unrestricted use, distribution, and reproduction in any medium, provided the original work is properly cited.

How to cite this article: Ibañez Valdés LdF, Geroge J, Joseph S et al. Case Report and Literature Review: COVID-19 and status epilepticus in Dyke-Davidoff-Masson syndrome [version 1; peer review: 2 approved] F1000Research 2021, 10:9

https://doi.org/10.12688/f1000research.27971.1

First published: 08 Jan 2021, 10:9 https://doi.org/10.12688/f1000research.27971.1 


\section{Introduction}

In 1580 , the first respiratory pandemic was reported ${ }^{1}$. Up to date, millions of people died, most of them during the $20^{\text {th }}$ and $21^{\text {st }}$ centuries. The most devastating epidemic and outbreaks were the Spanish Flu (500 million infected) during the early 20th century, even bigger than Hong Kong flu, swine flu, SARS-CoV-1 (2003), and the MERS-CoV outbreak (2012) ${ }^{1-3}$. However, the first pandemic causing encephalitis was reported soon after $1580^{3}$.

Since 1965, when human coronaviruses were discovered ${ }^{4}$, several types of coronavirus $(\mathrm{CoV})$ have been reported, including SARS-CoV-2, SARS-CoV-1, and MERS-CoV, which are all responsible for three epidemics, plus others four types that also infect many human beings (HCoV-229E, HCoV-OC43, HCoV-NL63, and HCoV-HKU1) ${ }^{5}$. Based on several mechanisms, coronaviruses affect the peripheral and the central nervous system. Even before SARS-CoV-2, other types of coronavirus, such as SARS-CoV-1, HCoV-229E, and HCoV-OC43, also damage the nervous system ${ }^{5}$.

Wuhan is a large city and the capital of Hubei Province in the People's Republic of China. Wuhan has a population of around 11 million persons. At the beginning of December 2019, an outbreak of many persons presenting viral pneumonia of an unknown agent was reported. In the following month (January 7, 2020), some Chinese authors identified the etiological agent of that respiratory disease and called it by 2019-nCoV (for 2019 novel coronavirus) ${ }^{6-8}$.

Since December 2019, documented an increasing number of cases presenting the novel coronavirus disease of 2019 (nCOVID-19) and associated neurological manifestation are published every month. CoV also caused neurological lesions like anosmia and ageusia with different prevalence in China $(5 \%)^{6}$ or in Italy $(88 \%)^{9}$.

In a recent study by Dorche et al., the following list of neurological complications were observed: headache and dizziness (the most common on initial presentation), fatal encephalitis with HCoV-OC43 (two immunosuppressed infants), acute disseminated encephalomyelitis (one 15-year-old boy with $\mathrm{HCoV}-\mathrm{OC} 43$ and four adults with SARS-CoV-2), acute flaccid paralysis (HCoV 229E) and OC43 (one 3-year-old girl), ischemic $(1.3 \%)$ and hemorrhage $(0.5 \%)$ strokes, encephalitis with SARS-CoV-1 RNA (one 39-year-old patient), different presentation of Guillain-Barré syndrome, cerebral venous sinus thrombosis (13 patients in nine studies), acute encephalomyelitis (four patients), acute myelitis (five patients), optic neuritis (one patient) altered level of consciousness (nonconvulsive status epilepticus, infections, parenchymal lesions, electrolyte disturbances, hypoxic, toxic and metabolic encephalopathies), leukoencephalopathy (18 patients in three studies), acute necrotizing encephalopathy (eight patients), other encephalitis (22 patients out of 13 reviews), mild encephalitis/encephalopathy with a reversible splenial lesion(MERS), posterior reversible encephalopathy syndrome (PRES), and Bickerstaff's encephalitis (BBE), ${ }^{10-14}$. In patients infected by SARS-CoV-1 and SARS-CoV-2, epileptic seizures have been reported ${ }^{13}$ also in infected patients with MERS-CoV ${ }^{12}$ and SARS-CoV-2. In COVID-19, (48 epileptic patients out of 20 studies), visual impairments (12 patients out of 3 reviews), impaired eye movement mainly due to Abducens nerve palsy (12 patients out of 4 reviews), trigeminal neuropathy (in 9 patients out of 2 studies), Miller-Fisher syndrome (52 patients out of 36 studies), skeletal muscle injury and muscular diseases Have been reported ${ }^{10}$.

Nepal and colleagues ${ }^{15}$ reported one case of Bell's palsy, as a neurological presentation of COVID-19. Another group of authors published two new patient cases but did not include enough supporting information to draw firm conclusions ${ }^{16}$. At the same time, other authors have published cases presenting generalized epileptic seizures ${ }^{17-22}$.

One case of focal status epilepticus (SE) was reported by Vollono et $a l .{ }^{23}$ and acute epileptic encephalopathy by others ${ }^{24-26}$, including the treatment for these conditions ${ }^{27}$.

A systematic review done by Ghannam et al. found two cases of SE, one of which had a past medical history of epilepsy from another cause ${ }^{28}$. Gelisse et al. established that some patients with severe SARS-CoV-2 infection are at risk of subclinical epileptic seizures or even nonconvulsive status epilepticus (NCSE) and recommend video EEG monitoring in some cases ${ }^{29}$.

Recently, some authors have speculated that acute epileptic seizures may be due to swelling of the brain cortex (encephalitis) and the direct damage of the brain cortex by the virus because SARS-CoV-2 can be present in the cerebrospinal fluid (CSF) of some patients ${ }^{18,30,31}$.

In other extensive studies involving several hundreds of COVID-19 patients, the authors concluded that none of their cases had acute symptomatic seizures or $\mathrm{SE}^{20,32-42}$.

Nevertheless, the retrospective case series published by Somani and collaborators ${ }^{25}$ deserves special mention. These investigators published the electroencephalographic findings and clinical manifestations of two COVID-19 patients with newonset SE without a previous history of epilepsy or acute epileptic seizures. Both patients had SARS-CoV-2 pneumonia confirmed by CT scan and PCR; however, the authors did not perform CSF and could not rule out meningoencephalitis. The second patient presented a new-onset refractory status epilepticus. The same author established the neurovirulence of SARS-CoV-1, finding the presence of viral antigen in the thalami, hippocampus, medulla oblongata, and mesencephalic regions that regulate cardiorespiratory functions in a human autopsy series ${ }^{25}$. Some recent good news is the excellent response of SE to levetiracetam reported by two investigators ${ }^{24,25}$.

Other investigators also recommend the use of verapamil in patients presenting SE stage III and SARS-Cov-2 infection ${ }^{43}$. The same authors reported the first patient affected by PRES and SARS-CoV-2 without SE. In contrast, Mohammad et al. wrote about a 32-year-old male with tonic-clonic generalized $\mathrm{SE}^{44}$. In the meantime, other investigators delivered essential 
recommendations to improve the management of SE during the pandemic despite the lack of ventilators and ICU facilities ${ }^{45}$.

Acquired or congenital (infantile) cerebral hemiatrophy, otherwise referred to as Dyke-Davidoff-Masson syndrome (DDMS), was first described in 1933 by Dyke and colleagues ${ }^{46-48}$. DDMS is a non-inherited rare condition ${ }^{49}$, with an unknown frequency; most of the literature stems from either case reports or series ${ }^{50}$. DDMS is a diagnostic constellation made up of hemiparesis/hemiplegia, facial asymmetry, intellectual disability, and treatment-resistant epilepsy, classically with distinct neuroimaging features ${ }^{48}$. However, according to Ayaz et al., the syndrome has varied clinical and radiological spectrum presenting at different life stages $^{51}$. The classical imaging findings are hypoplasia of one brain hemisphere (hemiatrophy), often accompanied by volume reduction of corresponding cranial fossa and thickening of nearby bony structures and equilateral enlargement paranasal sinuses, the frontal sinus being the most involved or hyperpneumotisation of mastoid air cells. The congenital type can be due to insults suffered during fetal or early childhood development, such as ischemia, trauma, infarction, hemorrhage, and infections. However, the acquired type is usually associated with trauma, infectious diseases, or hemorrhages after one month of age $e^{47}$. We know that hemispherectomy is the best treatment for patients who have drug-resistant and disabling seizures.

At the time of writing, the coronavirus disease-19 (COVID-19) pandemic continues infecting peoples worldwide. COVID-19, caused by SARS-CoV-2, has thus far claimed 23,057,288 cases worldwide ${ }^{52}$ and 607045 patients in South Africa ${ }^{53}$. Up to date, 46 medical doctors died in the Eastern Cape province alone.

We performed an extensive search of the medical literature to answer our research question: "What is the reported frequency of status epilepticus in patients with DDMS and coronavirus infections?

\section{Case presentation}

A 48-year-old African male patient was admitted to Nelson Mandela Academic Central Hospital (NMACH) in Mthatha, South Africa. He was born out of a non-consanguineous marriage and was referred from a regional hospital with tonic-clonic-generalized status epilepticus. On initial presentation to the base hospital, he was given diazepam $10 \mathrm{mg}$ IV stat (dose repeated twice) and then loaded with phenytoin $750 \mathrm{mg}$.

This patient had a past medical history of chronic epilepsy for many years but was well-controlled on valproate acid CR $500 \mathrm{mg}$ PO Bd, levetiracetam $750 \mathrm{mg}$ PO BD per day. There was no facial asymmetry, no hemiplegia, the rest of the cognitive functions were average, and there are no mental retardation signs.

He was also a chronic hypertensive. He worked as a police officer on further inquiry and he did not smoke, consume drugs or alcohol. We did not obtain remarkable information on birth history, developmental milestones, education history, prior admissions to hospital, and childhood illnesses.
We found no noticeable body asymmetry on examination. The patient had pink mucous membranes, was well hydrated, and afebrile with a GCS 11/15 (E3V3M5); his motor examination revealed a power $3 / 5$ with spastic hypertonia on left upper and lower limbs, and no fits noted.

He was in respiratory distress with tachypnea of 30 breaths/minute saturating at $84 \%$ on a $40 \%$ venture face mask. The rest of the vital signs showed a BP $118 / 88 \mathrm{mmHg}$ and Pulse $98 \mathrm{bpm}$. He had scattered crepitation on the chest bilaterally. Table 1 shows all blood test results.

Serum levels of interleukine-6 were not available. PCR confirmed SARS-CoV infection, but we did not perform ferritin and procalcitonin investigations.

The patient presented with a one-day SE type II (established), characterized by recurrent tonic-clonic generalized seizures

\section{Table 1. Blood test results.}

\begin{tabular}{|l|l|l|}
\hline Blood test variables & Patient value & Normal range \\
\hline White cell count & $5.30 \times 10^{9} / \mathrm{L}$ & $3.9-12.6 \times 10^{9} / \mathrm{L}$ \\
\hline $\mathrm{Hb}$ & $16.1 \mathrm{~g} / \mathrm{dL}$ & $12-15 \mathrm{~g} / \mathrm{dl}$ \\
\hline Platelets & $365 \times 10^{9} / \mathrm{L}$ & $186-454 \times 109 / \mathrm{L}$ \\
\hline Sodium & $141 \mathrm{mmol} / \mathrm{L}$ & $136-145 \mathrm{mmol} / \mathrm{L}$ \\
\hline Potassium & $3.8 \mathrm{mmol} / \mathrm{L}$ & $3.5-5.1 \mathrm{mmol} / \mathrm{L}$ \\
\hline Chloride & $113 \mathrm{mmol} / \mathrm{L}$ & $98-105 \mathrm{mmol} / \mathrm{L}$ \\
\hline Urea & $8.8 \mathrm{mmol} / \mathrm{L}$ & $2.1-7.1 \mathrm{mmol} / \mathrm{L}$ \\
\hline Creatinine & $122 \mu \mathrm{mol} / \mathrm{L}$ & $48-90 \mu \mathrm{mol} / \mathrm{L}$ \\
\hline Calcium & $2.20 \mathrm{mmol} / \mathrm{L}$ & $2.15-2.5 \mathrm{mmol} / \mathrm{L}$ \\
\hline Magnesium & $0.87 \mathrm{mmol} / \mathrm{L}$ & $0.63-1.05 \mathrm{mmol} / \mathrm{L}$ \\
\hline Phosphate & $1.40 \mathrm{mmol} / \mathrm{L}$ & $0.78-1.42 \mathrm{mmol} / \mathrm{L}$ \\
\hline C-reactive protein & $23 \mathrm{mg} / \mathrm{L}$ & $<10 \mathrm{mg} / \mathrm{L}$ \\
\hline $\begin{array}{l}\text { Erythrocyte } \\
\text { sedimentation rate }\end{array}$ & $12 \mathrm{~mm} / \mathrm{hr}$ & $0-10 \mathrm{~mm} / \mathrm{hr}$ \\
\hline Total protein & $72 \mathrm{~g} / \mathrm{L}$ & $60-78 \mathrm{~g} / \mathrm{L}$ \\
\hline Total Bilirubin & $<4 \mu \mathrm{mol} / \mathrm{L}$ & $5-21 \mu \mathrm{mol} / \mathrm{L}$ \\
\hline Alkaline phosphatase & $90 \mathrm{U} / \mathrm{L}$ & $42-98 \mathrm{U} / \mathrm{L}$ \\
\hline Aspartate transaminase & $23 \mathrm{U} / \mathrm{L}$ & $13-35 \mathrm{U} / \mathrm{L}$ \\
\hline Alanine transaminase & $19 \mathrm{U} / \mathrm{L}$ & $7-35 \mathrm{U} / \mathrm{L}$ \\
\hline Total cholesterol & $4.78 \mathrm{mmol} / \mathrm{L}$ & $<4.5 \mathrm{mmol} / \mathrm{L}$ \\
\hline HbA1C & $5.1 \%$ & $<7 \%$ \\
\hline Valproate level & $427 \mu \mathrm{mol} / \mathrm{L}$, & $346.70-693.40$ \\
\hline & $139 \mu \mathrm{mol} / \mathrm{L}$ & $20-40 \mu \mathrm{mol} / \mathrm{L}$ \\
\hline
\end{tabular}


with impaired awareness. As he did not recover, progressive doses of anti-seizure medication (ASM) were administered, reaching a total of $20 \mathrm{mg}$ of diazepam (10 mg IV twice), $1500 \mathrm{mg}$ of phenytoin (IV bolus), and $1500 \mathrm{mg}$ of valproate $(25 \mathrm{mg} / \mathrm{kg})$, without recovering. An urgent cranial CT scan of the brain revealed atrophy on the right cerebral hemisphere with associated thickening of the calvarium on the same side without hyperpneumotisation of paranasal sinuses or mastoid air cells (Figure 1, Figure 2 and Figure 3), suggestive of

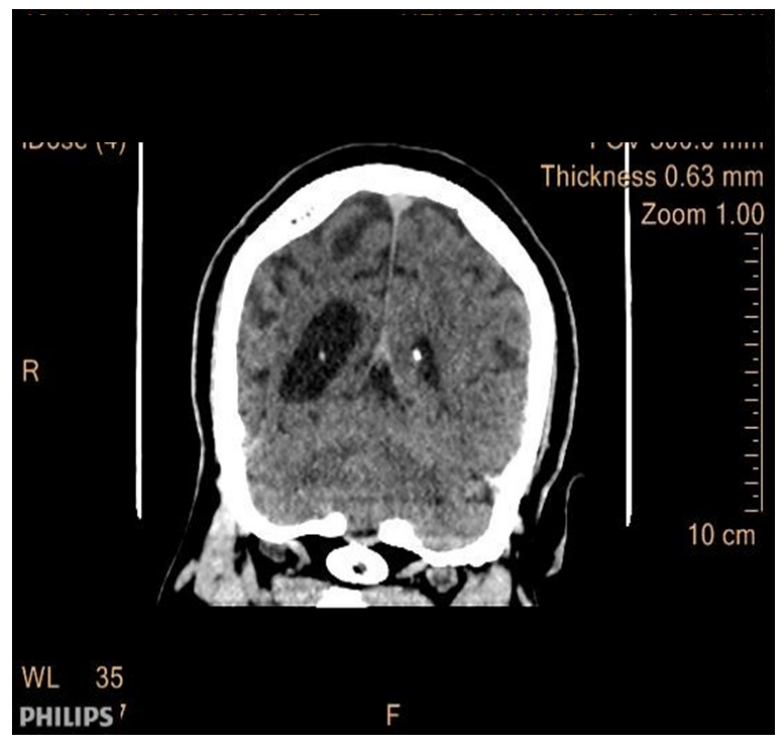

Figure 1. CT scan of the brain (coronal view). Shows a notable atrophy of the right cerebral hemisphere with enlargement of the ipsilateral lateral ventricle.

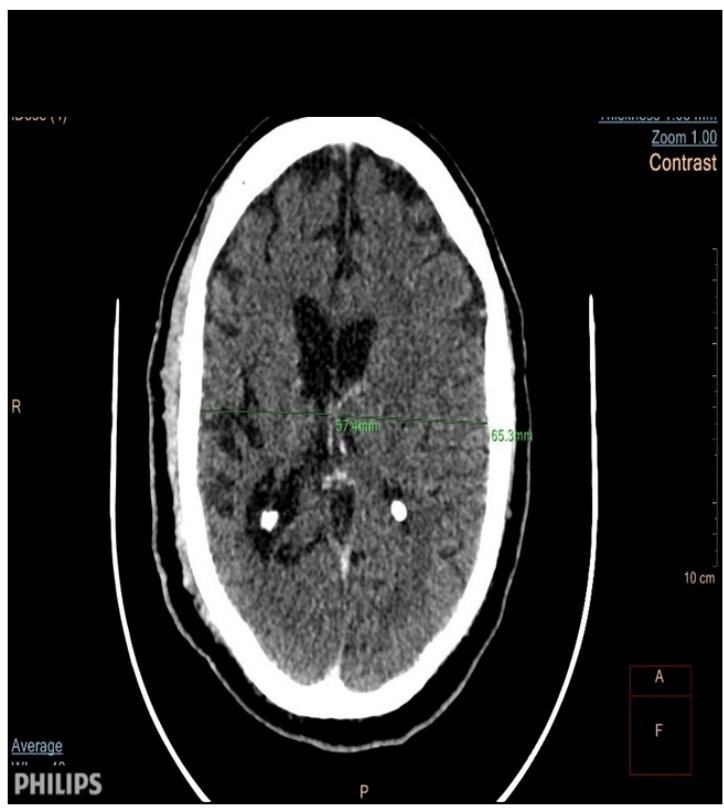

Figure 2. CT scan of the brain (axial view). Shows asymmetry of the lateral ventricles (right to left) with a notable atrophy of the right cerebral hemisphere.

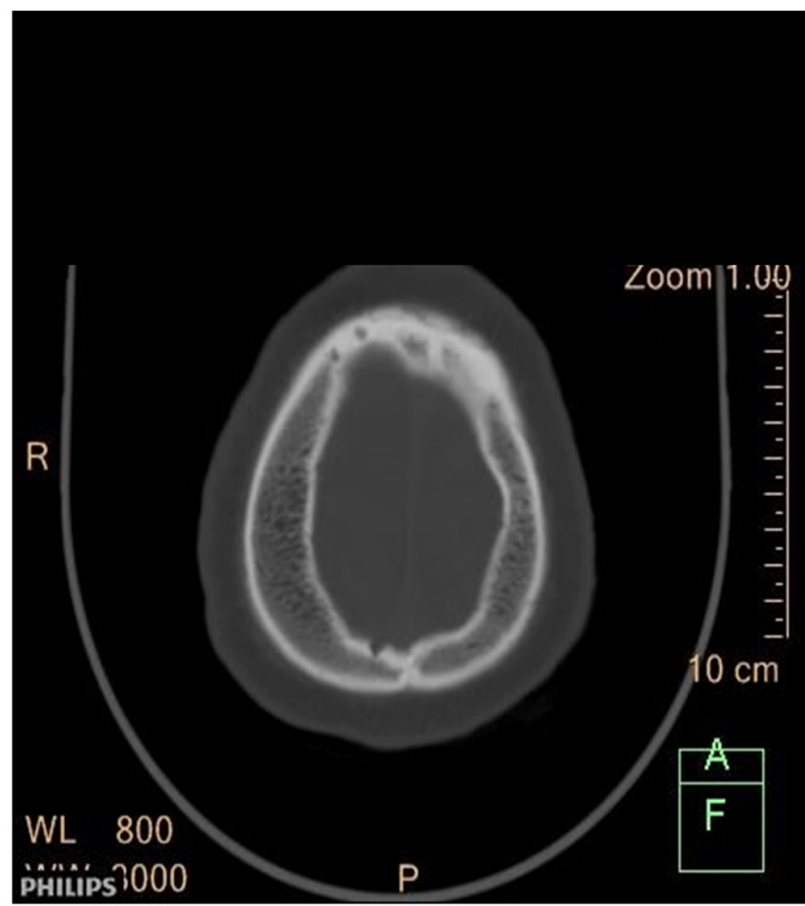

Figure 3. CT scan of the head (axial view). Shows a marked thickness on the right side of the skull.

Dyke-Davidoff-Masson Syndrome; otherwise, there was no bleed or area of infarct, and there was no space-occupying lesion.

On the second day of admission, the patient was admitted to the COVID ward, put on high-flow nasal oxygen $(60 \%$ at $15 \mathrm{~L} / \mathrm{min}$ ), dexamethasone $8 \mathrm{mg}$ IV daily, Clexane $60 \mathrm{mg}$ SC 12-hourly, ceftriaxone $1 \mathrm{~g}$ IV every day, azithromycin $500 \mathrm{mg}$ Po daily, vitamin D $50000 \mathrm{U}$ PO weekly, vitamin C $250 \mathrm{mg}$ PO 8-hourly, diazepam $10 \mathrm{mg}$ IV if fitting, valproate $500 \mathrm{mg}$ IV 12-hourly, phenytoin $100 \mathrm{mg}$ IV 8-hourly, amlodipine $10 \mathrm{mg}$ orally daily, Ridaq $25 \mathrm{mg}$ orally daily and intravenous fluids (1 L Ringers lactate IV 8-hourly).

After two days of admission, the patient improved neurologically and presented no more seizures, but his respiratory distress continued progressively getting worse, and his septic markers were rising. Two days later, blood levels showed values of $\mathrm{Na} 159 \mathrm{mmol} / \mathrm{L}$, K $5.1 \mathrm{mmol} / \mathrm{L}$, urea $42 \mathrm{mmol} / \mathrm{L}$, creatinine $275 \mu \mathrm{mol} / \mathrm{L}$, CRP $117 \mathrm{mg} / \mathrm{dL}$, T protein $88 \mathrm{~g} / \mathrm{L}$, Alb $38 \mathrm{~g} / \mathrm{L}$, ALT $48 \mathrm{U} / \mathrm{L}$, AST $168 \mathrm{U} / \mathrm{L}$, GGT $190 \mathrm{U} / \mathrm{L}$, ALP 58U/L, white cell count $14.30 \times 10^{9} / \mathrm{L}, \mathrm{Hb} 17.1 \mathrm{~g} / \mathrm{dl}$, platelet count $316 \times 10^{9} / \mathrm{L}$ cholesterol level no done, Blood gas showed $\mathrm{Ph}$. 7.46, $\mathrm{PaCO}_{2} 36 \mathrm{mmHG}, \mathrm{PaO}_{2} 66 \mathrm{mmHg}, \mathrm{HCO}_{3} 27 \mathrm{mmol} / \mathrm{L}$, $\mathrm{Na} 160 \mathrm{mmol} / \mathrm{L}, \quad \mathrm{K} \quad 3.5 \mathrm{mmol} / \mathrm{L}$, Ca $1.05 \mathrm{mmol} / \mathrm{L}$, Hgt $25.6 \mathrm{mmol} / \mathrm{L}$, blood oxygen saturation $84 \%$. The patient's urine did not contain ketone bodies.

On the fifth day after admission, the patient was assessed as having ARDS secondary to COVID-19 and hyperglycemic hyperosmolar state (HHS), and high-flow nasal $\mathrm{O}_{2}$ was increased to $100 \%$ concentration at $20 \mathrm{~L} / \mathrm{min}$. One and a half 
hours after the onset of the symptoms, the patient had not recovered yet. The patient began to fit again and under the suspicion of refractory status epilepticus secondary to HHS and neuro-COVID 19; when another round of $20 \mathrm{mg}$ of diazepam (10 mg IV twice), $1500 \mathrm{mg}$ of phenytoin (IV bolus), and $1500 \mathrm{mg}$ of valproate $(25 \mathrm{mg} / \mathrm{kg})$ was started, the patient developed cardiac arrest and demised.

\section{Discussion and literature review}

Our literature review utilized the Preferred Reporting Items for Systemic review and Meta-Analysis statement. However, we did not conduct a classical systematic review.

We reviewed the databases published before August 20, 2020, such as Medline EMBASE, Scopus online databases, Google Scholar, to identify articles evaluating COVID-19 and SE in DDMS. All items about "neurologic complications* OR epilepsy* OR brain* OR status epilepticus* OR fits* OR neuronal lesion* OR Neuro-Covid* OR cortical lesions* OR DDMS OR * OR seizure* OR COVID-19* OR unconsciousness* OR acute epileptic seizure*, OR Duke Davidoff Mason Syndrome*" where * is the PubMed wildcard for every possible word beginning or ending. Other neurological combinations were considered beyond the scope of the current work and no included. Finally, we did not find a publication related to COVID-19, SE and DDMS.

Our patient complained of chronic arterial hypertension, and this condition and diabetes mellitus is associated with a significant risk of lung disease leading to COVID-19 severity. Despite the patient's condition, antihypertensive therapy should continue in COVID-19 patients ${ }^{54}$. Concerning our patient, it's important to highlight that diabetes mellitus by itself is one of the most relevant comorbidities associated with the severity of all coronavirus infections, including the current SARS-CoV-2, and affected cases have an increased risk to develop severe complications such as acute respiratory distress syndrome and systemic organ failure ${ }^{55}$. COVID-19 patients with hyperglycemia are at risk of developing other infections, including influenza and pneumonia with increasing mortality rate; this is also applicable to other SARS coronavirus, pandemic influenza A 2009 (H1N1), and middle east respiratory syndrome coronavirus ${ }^{56-59}$.

Here we discuss elevated urea and creatinine in our patient. Therefore, it is essential to mention that apart from diabetes and hypertension, acute kidney injury has also been documented in some patients with COVID-19. ACE2 gene expression in renal cells and bladders cells has been investigated, and the results confirmed damage of the renal proximal tubule cells and the bladder epithelial cells by COVID-19 infection ${ }^{60}$. SARS-CoV-2 affects the kidneys ${ }^{61}$, which has been confirmed by examining viral nucleocapsid protein accumulated in the renal tubules by post-mortem examination proved that ${ }^{62}$.

DDMS is due to atrophy of one cerebral hemisphere and usually occurs due to an insult to the brain in utero or an early period of childhood ${ }^{63}$. In the first description, Dyke, Davidoff, and Masson described nine patients who had a constellation of seizures, facial asymmetry, mental retardation, and hemiparesis with bare skull X-ray changes (ipsilateral osseous hypertrophy and calvarial thickening $)^{64}$. We can understand intracranial pathology with MRI and CT scans, which results in such clinical presentation. Our patient is atypical because he did not complain of weakness on the left half body, was strong enough to work as a police officer, and there was no evidence of mental retardation was observed.

Some patients with DDMS can complain of psychiatric manifestations in rare instances ${ }^{65}$. The radiological features can include unilateral cerebral atrophy, calvarial thickening, and hyperpneumotisation of the paranasal sinuses ${ }^{66}$. As with our patient, mental retardation does not always need to be present, and the seizures may develop years after the initial insult ${ }^{67}$.

Some authors classify DDMS as either congenital/primary or acquired/secondary. The congenital form occurs due to an insult that happens in utero. It could be infections or vascular disorders occurring during the gestational period (unilateral cerebral artery pathologies or mid aortic arch coarctation $)^{68}$. The congenital forms usually present during the perinatal period. The acquired form occurs due to early childhood infections, trauma, tumors, asphyxia, intracranial ischemia, or hemorrhage.

To better understand the anatomical changes occurring, it is crucial to understand the brain's growth and surrounding structure. The mail sulci form around 3 months' gestation up to approximately eight months of pregnancy. If there are no prominent sulci visible on imaging, the congenital form of DDMS is present. Most brain and skull development occurs during the first three years of life (reaching $75 \%$ of adult size). The outward pressure of the brain parenchyma on the skull contributes to this growth. If there is unilateral atrophy, then the surrounding structures will grow inwards (calvarial thickening, enlarged sinuses, increased width of diploid $\operatorname{spaces}^{69,70}$. Hangmen et al. proposed that the congenital form of DDMS be named unilateral cerebral hypoplasia because there is hypoplasia instead of atrophy ${ }^{71}$.

A literature review done by Unal et al. showed that in the pediatric presentations, there is a male predisposition towards DDMS, and the left hemisphere is more commonly affected; the mean age at diagnosis was 11 in this review ${ }^{72}$. However, a literature review done by Diestro et al. in 2018 comprising 21 patients with a mean age at presentation being 31 years old showed a slight female despondence, and these adult presentations more commonly involving the right cerebral hemisphere. In $28 \%$ of cases $(6 / 21)$, there was no mental retardation, and in $14 \%(3 / 21)$, it was unknown whether there was mental retardation ${ }^{73}$.

The association of SARS-CoV and seizures was known even before the current pandemic. In 2003 authors published the first observed case ${ }^{74}$. The following year, other patients were reported $^{75}$, and later another case was associated with a different 
coronavirus $^{76}$. However, the total number of reported cases is small. SE and encephalopathy have been reported in children as a presentation of COVID-19. The mechanism of production of seizures is also known ${ }^{77}$. These authors ${ }^{77,78}$ proposed that epileptic seizures can be due to several mechanisms, such as direct infection of the virus, a post-infectious mechanism, an autoimmune response, hematogenous pathway and thrombosis ${ }^{79}$, by dysregulated cytokine storm $^{79}$, and by the retrograde neural way, hypoxia, and via the ACE-2 enzyme ${ }^{80}$.

Association between DDMS and SE is hugely uncommon, and before the current COVID-19 pandemic, only three adolescent patients have been reported: one in $2015^{81}$ and the other two in $2018^{82}$. Other recent systematic reviews, case series, and case reports did not mention any association of DDMS and $\mathrm{SE}^{51,63,73,83-90}$. At the time of writing (August 25, 2020), no patients presenting DDMS and SE infected by COVID-19 have been reported to the medical literature.

Differential diagnoses, such as Silver-Russell syndrome, basal ganglia germinoma, neurofibromatosis, Parry-Romberg Syndrome, Sturge-Weber syndrome, Rasmussen encephalitis, Fishman syndrome, linear nevus syndrome, and Rasmussen encephalitis, should be considered during the management of these patients.

Finally, we want to highlight some precautions to be considered when treating patients in SE and COVID-19. As aforementioned, DDMS causes epilepsy, epileptic seizures, and even SE. On the other hand, COVID-19 can also cause epileptic seizures and SE. However, the use of some ASM and anti-COVID medicines may cause complications. Therefore, some medications should be used with caution. For example, lacosamide is recommended for the adjunctive treatment of partial-onset seizures, diabetic neuropathic pain, and to control attacks in refractory SE. However, it can prolong the PR interval on an electrocardiogram. Hydroxychloroquine extends the QT interval $^{91}$. Elongation of the QT interval can also be caused by azithromycin, phenytoin, carbamazepine, and rufinamide, leading to cardiac conduction disturbances ${ }^{13}$. Combining ASM with hydroxychloroquine and azithromycin can be harmful. Therefore, we recommend EKG monitoring.

\section{Conclusion}

In our opinion, the SE in our patient had a multifactorial origin, including HHS and atypical DDMS. This could have created a susceptible environment in which the new coronavirus's disease acted as a SE trigger. These hypotheses make this case a unique report.

To our knowledge, this patient is the first case of SARS-CoV-2 infection leading to TCG-SE type 2 on a DDMS patient published in the medical literature.

\section{Data availability}

All data underlying the results are available as part of the article and no additional source data are required.

\section{Consent}

Written informed consent for publication of their clinical details and clinical images was obtained from the relatives of the patient.

\section{Author contributions}

Study concept and design: HFS, LFIV, and JG Data collection: WM, JG, and MS Analysis and interpretation of the references: LFIV. Drafting of the manuscript: LFIV, HFS. Revising the manuscript: SJ, MS, WM, and LFIV. Supervision of research and manuscript writing process: HFS and LFIV. All named authors meet the International Committee of Medical Journal Editors (ICMJE) criteria for authorship for this article, take responsibility for the work's integrity, and have given their approval for this version to be published.

\section{Acknowledgments}

Special thanks to Dr. A Anwary from the Department of Radiology, NMACH. Mthatha, South Africa, for his report on images.
1. Martin PMV, Martin-Granel E: 2,500-year evolution of the term epidemic. Emerg Infect Dis. 2006; 12(6): 976-980.

PubMed Abstract | Publisher Full Text | Free Full Text

2. Troyer EA, Kohn JN, Hong S: Are we facing a crashing wave of neuropsychiatric sequelae of COVID-19. Neuropsychiatric symptoms and potential immunologic mechanisms. Brain Behav Immun. 2020; 87: 34-39. PubMed Abstract | Publisher Full Text | Free Full Text

3. Cunha BA: Influenza: historical aspects of epidemics and pandemics. Infect Dis Clin North Am. 2004; 18(1): 141-155. PubMed Abstract | Publisher Full Text

4. Kahn JS, McIntosh K: History and recent advances in coronavirus discovery. Pediatr Infect Dis J. 2005; 24(11 Suppl): S223- S227. PubMed Abstract | Publisher Full Text

5. Zhu N, Zhang D, Wang W, et al.: A novel coronavirus from patients with pneumonia in China, 2019. N EnglJ Med. 2020; 382(8): 727-733. PubMed Abstract | Publisher Full Text | Free Full Text

6. Schwartz DA, Graham AL: Potential Maternal and Infant Outcomes from
Coronavirus 2019-nCoV (SARS-CoV-2) Infecting Pregnant Women: Lessons from SARS, MERS, and Other Human Coronavirus Infections. Viruses. 2020; 12(2): 194.

PubMed Abstract | Publisher Full Text | Free Full Text

7. Ma K, chen T, Han MF: [Management and clinical thinking of Coronavirus Disease 2019]. Zhonghua Gan Zang Bing Za Zhi. 2020; 28(0): E002. PubMed Abstract | Publisher Full Text

8. Mao L, Jin $\mathrm{H}$, Wang $\mathrm{M}$, et al.: Neurologic Manifestations of Hospitalized Patients With Coronavirus Disease 2019 in Wuhan, China. JAMA Neurol. 2020; 77(6): 683-690.

PubMed Abstract | Publisher Full Text | Free Full Text

9. Lechien JR, Chiesa-Estomba CM, Cabaraux P, et al.: Features of Mild-toModerate COVID-19 Patients with Dysphonia.J Voice. 2020; S08921997(20)30183-1.

PubMed Abstract | Publisher Full Text | Free Full Text

10. Dorche MS, Huot Ph, Osherov M, et al.: Neurological complications of coronavirus infection; a comparative review and lessons learned during 
the COVID-19 pandemic. J Neurol Sci. 2020; 417: 117085 PubMed Abstract | Publisher Full Text | Free Full Text

11. Pinna P, Grewal P, Hall JP, et al.: Neurological manifestations, and CoVID-19: Experiences from a tertiary care center at the Frontline. J Neurol Sci. 2020; 415: 116969.

PubMed Abstract | Publisher Full Text

12. Jain $R$, Young $M$, Dogra $S$, et al.: COVID-19 related neuroimaging findings: $A$ signal of thromboembolic complications a strong prognostic marker of poor patient outcome. J Neurol Sci. 2020; 414: 116923.

PubMed Abstract | Publisher Full Text | Free Full Text

13. Asadi-Pooya AA: Seizures associated with coronavirus infections. Seizure. 2020; 79: 49-52.

PubMed Abstract | Publisher Full Text | Free Full Text

14. Chen $\mathrm{T}$, Wu $\mathrm{D}$, Chen $\mathrm{H}$ : Clinical characteristics of $\mathbf{1 1 3}$ deceased patients with coronavirus disease 2019: a retrospective study. BMJ. 2020; 368: m1091. PubMed Abstract | Publisher Full Text | Free Full Text

15. Nepal G, Rehrig JH, Shrestha GS, et al.: Neurological manifestations of COVID19: a systematic review. Crit Care. 2020; 24(1): 421 PubMed Abstract | Publisher Full Text | Free Full Text

16. Pinzon RT, Wijaya VO, Buana RB, et al.: Neurologic Characteristics in Coronavirus Disease 2019 (COVID-19): A Systematic Review and MetaAnalysis. Front Neurol. 2020; 11: 565

PubMed Abstract | Publisher Full Text | Free Full Text

17. Hao X, Zhou D, Li Z, et al.: Severe psychological distress among epilepsy patients during the COVID-19 outbreak in southwest China. Epilepsia. 2020; 61(6): 1166-1173.

PubMed Abstract | Publisher Full Text | Free Full Text

18. Moriguchi T, Harii N, Goto J, et al.: A first case of meningitis/encephalitis associated with SARS-Coronavirus-2. Int J Infect Dis. 2020; 94: 55-58. PubMed Abstract | Publisher Full Text | Free Full Text

19. Duong $L, X u P, L i u A$ : Meningoencephalitis without respiratory failure in young female patient with COVID-19 infection in downtown Los Angeles, early April 2020. Brain Behav Immun. 2020; 87: 33 PubMed Abstract | Publisher Full Text | Free Full Text

20. Lu L, Xiong W, Liu D, et al.: New-onset acute symptomatic seizure and risk factors in coronavirus disease 2019: a retrospective multicenter study. Epilepsia. 2020; 61(6): e49-e53.

PubMed Abstract | Publisher Full Text | Free Full Text

21. Fasano A, Cavallieri $F$, Canali $E$, et al:: First motor seizure as presenting symptom of SARS-CoV-2 infection. Neurol Sci. 2020; 41(7): 1651-1653. PubMed Abstract | Publisher Full Text | Free Full Text

22. Leonardi M, Padovani A, McArthur JC: Neurological manifestations associated with COVID-19: a review and a call for action. J Neurol. 2020 267(6): 1573-1576.

PubMed Abstract | Publisher Full Text | Free Full Text

23. Vollono $C$, Rollo $E$, Romozzi $M$, et al.: Focal status epilepticus as a unique clinical feature of COVID-19: a case report. Seizure. 2020; 78: 109-112. PubMed Abstract | Publisher Full Text | Free Full Text

24. Balloy G, Leclair-Visonneau L, Péréon $Y$, et al.: Non-lesional status epilepticus in a patient with coronavirus disease 2019. Clin Neurophysiol. $2020 ; 131(8)$ : 2059-2061.

PubMed Abstract | Publisher Full Text | Free Full Text

25. Somani S, Pati S, Gaston T, et al.: De Novo status epilepticus in patients with COVID-19. Ann Clin Transl Neurol. 2020; 7(7): 1240-1244. PubMed Abstract | Publisher Full Text | Free Full Text

26. Katal S, Balakrishnan S, Gholamrezanezhad A: Neuroimaging and neurologic findings in COVID-19 and other coronavirus infections: A systematic review in 116 patients. J Neuroradiol. 2020; S0150-9861(20)30204-2. PubMed Abstract | Publisher Full Text | Free Full Text

27. Orsucci D, Ienco EC, Nocita G, et al.: Neurological features of COVID-19 and their treatment: a review. Drugs Context. 2020; 9: 2020-5-1. PubMed Abstract | Publisher Full Text | Free Full Text

28. Ghannam M, Alshaer Q, Al-Chalabi M, et al.: Neurological involvement of coronavirus disease 2019: a systematic review. J Neurol. 2020; 267(11): 3135-3153.

PubMed Abstract | Publisher Full Text | Free Full Text

29. Gelisse P, Rossetti AO, Genton P, et al.: How to carry out and interpret EEG recordings in COVID-19 patients in ICU. Clin Neurophysiol. 2020; 131( 8): 2023-2031.

PubMed Abstract | Publisher Full Text | Free Full Text

30. Niazkar HR, Zibaee B, Nasimi A, et al.: The neurological manifestations of COVID-19: a review article. Neurol Sci. 2020; 41(7): 1667-1671. PubMed Abstract | Publisher Full Text | Free Full Text

31. Chen X, Laurent S, Onur OA, et al.: A systematic review of neurological symptoms and complications of COVID-19. J Neurol. 2020; 1-11. PubMed Abstract | Publisher Full Text | Free Full Tex

32. Wang $L$, Shen $Y, L i M$, et al.: Clinical manifestations and evidence of neurological involvement in 2019 novel coronavirus SARS-CoV-2: a systematic review and meta-analysis. J Neurol. 2020; 267(10): 2777-2789. PubMed Abstract | Publisher Full Text | Free Full Text

33. Butala N: Neurological Aspects of Coronavirus Infectious Disease 2019 (COVID-19). Innov Clin Neurosci. 2020; 17(4-6): 13-15. PubMed Abstract | Free Full Text
34. García-Azorín D, Martínez-Pías E, Trigo J, et al.: Neurological Comorbidity Is a Predictor of Death in Covid-19 Disease: A Cohort Study on 576 Patients. Front Neurol. 2020; 11: 781.

PubMed Abstract | Publisher Full Text | Free Full Text

35. Bridwell R, Long B, Gottlieb M: Neurologic complications of COVID-19. Am J Emerg Med. 2020; 38(7): 1549.e3-1549.e7.

PubMed Abstract | Publisher Full Text | Free Full Text

36. Alomari SO, Abou-Mrad Z, Bydon A: COVID-19 and the Central Nervous System. Clin Neurol Neurosurg. 2020; 198: 106116. PubMed Abstract | Publisher Full Text | Free Full Text

37. Yavarpour-Bali $\mathrm{H}$, Ghasemi-Kasman M: Update on neurological manifestations of COVID-19. Life Sci. 2020; 257: 118063. PubMed Abstract | Publisher Full Text | Free Full Text

38. Needham EJ, Chou SHY, Coles AJ, et al:: Neurological Implications of COVID19 Infections. Neurocrit Care. 2020; 32(3): 667-671. PubMed Abstract | Publisher Full Text | Free Full Text

39. Sheraton $\mathrm{M}$, Deo N, Kashyap R, et al.: A Review of Neurological Complications of COVID-19. Cureus. 2020; 12(5): e8192. PubMed Abstract | Publisher Full Text | Free Full Text

40. Mao L, Jin $\mathrm{H}$, Wang $\mathrm{M}$, et al.: Neurologic manifestations of hospitalized patients with coronavirus disease 2019 in Wuhan, China. JAMA Neurol. 2020; 77(6): 683-690.

PubMed Abstract | Publisher Full Text | Free Full Text

41. Ellul MA, Benjamin L, Singh B, et al:: Neurological associations of Covid-19. Lancet Neurol. 2020; 19(9): 767-783.

PubMed Abstract | Publisher Full Text | Free Full Text

42. Garg RK: Spectrum of Neurological Manifestations in Covid-19: A Review. Neurol India. 2020; 68(3): 560-572.

PubMed Abstract | Publisher Full Text

43. Gómez-Enjuto S, Hernando-Requejo V, Lapeña-Motilva J, et al.: Verapamil as treatment for refractory status epilepticus secondary to PRES syndrome on a SARS-Cov-2 infected patient. Seizure. 2020; 80: 157-158. PubMed Abstract | Publisher Full Text | Free Full Text

44. Abdulsalam MA, Abdulsalam AJ, Shehab D: Generalized status epilepticus as a possible manifestation of COVID-19. Acta Neurol Scand. 2020; 142(4): 297-298.

PubMed Abstract | Publisher Full Text | Free Full Text

45. Kinney MO, Brigo F, Kaplan PW: Optimizing status epilepticus care during the COVID-19 pandemic. Epilepsy Behav. 2020; 109: 107124. PubMed Abstract | Publisher Full Text | Free Full Text

46. Dyke C, Davidoff L, Masson C: Cerebral hemiatrophy \& homolateral atrophy of the skull and sinuses. Surg Gynecol Obs. 1932; 57: 588-600.

47. Dilber B, Sahin S, Eyüboğlu I: Two Different Manifestations of Neonatal Vascular Injury: Dyke-Davidoff-Masson Syndrome and Crossed Cerebellar Atrophy. J Stroke Cerebrovasc Dis. 2020; 29(3): 104600.

PubMed Abstract | Publisher Full Text

48. Adebayo PB, Bakare A, Bello MM, et al.: Dyke-Davidoff-Masson syndrome in a Nigerian. Epilepsy Behav Case Rep. 2016; 7: 10-12 PubMed Abstract | Publisher Full Text | Free Full Text

49. Kalaskar R, Kalaskar AR: Classical oral manifestations of Dyke-DavidoffMasson syndrome: A case report with review of the literature. J Korean Assoc Oral Maxillofac Surg. 2018; 44(4): 198-203.

PubMed Abstract | Publisher Full Text | Free Full Text

50. Rashid AMA, Md Noh MSF: Dyke-Davidoff-Masson syndrome: a case report. BMC Neurol. 2018 [cited 2020 Aug 15]; 18(1): 76. PubMed Abstract | Publisher Full Text | Free Full Text

51. Bjelan M, Kozic D, Njagulj V, et al:: DYKE-DAVIDOFF-MASSON SYNDROME - TYPICAL IMAGING FEATURES. Med Pregl. 2016; 69(11-12): 373-5. PubMed Abstract | Publisher Full Text

52. Coronavirus disease (COVID-19). [cited 2020 Aug 25]. Reference Source

53. COVID-19 South African coronavirus news and information. [cited 2020, August 20]. Reference Source

54. Sanchis-Gomar F, Lavie CJ, Perez-Quilis C, et al.: Angiotensin-Converting Enzyme 2 and Antihypertensives (Angiotensin Receptor Blockers and Angiotensin-Converting Enzyme Inhibitors) in Coronavirus Disease 2019. Mayo Clin Proc. 2020; 95(6): 1222-1230. PubMed Abstract | Publisher Full Text | Free Full Text

55. Bornstein SR, Rubino F, Khunti K, et al.: Practical recommendations for the management of diabetes in patients with COVID-19. Lancet Diabetes Endocrinol. 2020; 8(6): 546-550. PubMed Abstract | Publisher Full Text | Free Full Text

56. Gupta R, Ghosh A, Singh AK, et al:: Clinical considerations for patients with diabetes in times of COVID-19 epidemic. Diabetes Metab Syndr. 2020; 14(3): 211-212. PubMed Abstract | Publisher Full Text | Free Full Text

57. Yang JK, Feng Y, Yuan MY, et al.: Plasma glucose levels and diabetes are independent predictors for mortality and morbidity in patients with SARS. Diabet Med. 2006; 23(6): 623-628. PubMed Abstract | Publisher Full Text

58. Schoen K, Horvat N, Guerreiro NFC, et al.: Spectrum of clinical and 
radiographic findings in patients diagnosed with H1N1 and correlation with clinical severity. BMC Infect Dis. 2019; 19(1): 964.

PubMed Abstract | Publisher Full Text | Free Full Text

59. Song $Z, X u Y, B a o L$, et al.: From SARS to MERS, thrusting coronaviruses into the spotlight. Viruses. 2019; 11(1): 59

PubMed Abstract | Publisher Full Text | Free Full Text

60. Lin W, Hu L, Zhang Y, et al:: Single-cell analysis of ACE2 expression in human kidneys and bladders reveals a potential route of 2019-nCoV infection. bioRxiv. 2020; (Reviewed on August 23, 2020). Publisher Full Text

61. Diao $B$, Feng $Z$, Wang $C$, et al.: Human kidney is a target for novel severe acute respiratory syndrome coronavirus 2 (SARS-CoV-2) infection. medRxiv. 2020.

Publisher Full Text

62. Perico L, Benigni A, Remuzzi G: Should COVID-19 concern nephrologists? Why and to what extent? The emerging impasse of angiotensin blockade. Nephron. 2020; 144(5): 213-221.

PubMed Abstract | Publisher Full Text | Free Full Text

63. Jilowa CS, Meena PS, Rohilla J, et al.: Dyke-Davidoff-Masson syndrome. Neurol India. 2017; 65(2): 413-4.

PubMed Abstract | Publisher Full Text

64. Dyke CG, Davidoff LM, Masson CB: Cerebral hemiatrophy and homolateral hypertrophy of the skull and sinuses. Surg Gynecol Obstet. 1933; 57: 588-600.

65. Amann B, Garcia de la Iglesia C, Mckenna P, et al.: Treatment-refractory schizoaffective disorder in a patient with dyke-davidoff-masson syndrome. CNS Spectr. 2009; 14(1): 36-9.

PubMed Abstract | Publisher Full Text

66. Pendse NA, Bapna P, Menghani V, et al.: Dyke-Davidoff-Masson syndrome (DDMS). Indian J Pediatr. 2004; 71(10): 943.

PubMed Abstract | Publisher Full Text

67. Sener RN, Jinkins JR: MR of craniocerebral hemiatrophy. Clin Imaging. 1992; 16(2): 93-7.

PubMed Abstract | Publisher Full Text

68. Graham A, Molnar Z: Development of the nervous system. In Standring S (ed): Gray's Anatomy, ed 40. London, Churchill Livingstone, Elsevier. 2008; 385.

69. Solomon GE, Hilal SK, Gold AP, et al.: Natural history of acute hemiplegia of childhood. Brain. 1970; 93(1): 107-120.

PubMed Abstract | Publisher Full Text

70. Sharma S, Goyal D, Negi A, et al.: Dyke-Davidoff-Masson syndrome. Indian J Radiol Imaging. 2006: 16(2): 165-6. Publisher Full Text

71. Hageman G, Gooskens RH, Willemse J: A cerebral cause of arthrogryposis: Unilateral cerebral hypoplasia. Clin Neurol Neurosurg. 1985; 87(2): 119-22. PubMed Abstract | Publisher Full Text

72. Unal O, Tombul T, Cirak B, et al.: Left hemisphere and male sex dominance of cerebral hemiatrophy (Dyke-Davidoff-Masson Syndrome). Clin Imaging. 2004; 28(3): 163-5.

PubMed Abstract | Publisher Full Text

73. Diestro JDB, Dorotan MKC, Camacho AC, et al.: Clinical spectrum of DykeDavidoff-Masson syndrome in the adult: an atypical presentation and review of literature. BMJ Case Rep. 2018; 2018: bcr2018224170. PubMed Abstract | Publisher Full Text | Free Full Text

74. Hung ECW, Chim SSC, Chan PKS, et al.: Detection of SARS coronavirus RNA in the cerebrospinal fluid of a patient with severe acute respiratory syndrome. Clin Chem. 2003; 49(12): 2108-2109.

PubMed Abstract | Publisher Full Text | Free Full Text

75. Lau KK, Chu CM, Lau ST, et al.: Possible central nervous system infection by SARS coronavirus. Emerg Infect Dis. 2004; 10(2): 342-344. PubMed Abstract | Publisher Full Text | Free Full Text

76. Dominguez SR, Robinson CC, Holmes KV: Detection of four human coronaviruses in respiratory infections in children: a one-year study in Colorado. J Med Virol. 2009; 81(9): 1597-1604.

PubMed Abstract | Publisher Full Text | Free Full Text

77. Swarz JA, Daily S, Niemi E, et al.: COVID-19 Infection Presenting as AcuteOnset Focal Status Epilepticus. Pediatr Neurol. 2020; 112: 7 . PubMed Abstract | Publisher Full Text | Free Full Text

78. McAbee GN, Brosgol Y, Pavlakis S, et al.: Encephalitis Associated with COVID19 infection in an 11-Year-Old Child. Pediatr Neurol. 2020; 109: 94. PubMed Abstract | Publisher Full Text | Free Full Text

79. Pedersen SF, Ho YC: SARS-CoV-2: a storm is raging. J Clin Invest. 2020; 130(5): 2202-2205

PubMed Abstract | Publisher Full Text | Free Full Text

80. Wu Y Xu X, Chen $Z$, et al: Nervous system involvement after infection with COVID-19 and other coronaviruses. Brain Behav Immun. 2020; 87: 18-22. PubMed Abstract | Publisher Full Text | Free Full Text

81. Zawar I, Khan AA, Sultan T, et al.: Dyke-Davidoff-Masson Syndrome. An unusual cause of status epilepticus. Neurosciences (Riyadh). 2015; 20(4): 385-7.

PubMed Abstract | Free Full Text

82. Alam M, Haq MAU, Ali F, et al.: Dyke-Davidoff-Masson Syndrome: An Unusual Cause of Status Epilepticus and Refractory Seizures. J Coll Physicians Surg Pak. 2018; 28(6): S99-101. PubMed Abstract

83. Roy U, Panwar A, Mukherjee A, et al.: Adult Presentation of Dyke-DavidoffMasson Syndrome: A Case Report. Case Rep Neurol. 2016; 8(1): 20-6. PubMed Abstract | Publisher Full Text | Free Full Text

84. Shahid R: An unusual presentation of Dyke-Davidoff Masson syndrome. Neurosciences (Riyadh). 2018; 23(3): 254-257. PubMed Abstract | Publisher Full Text

85. Malik P, Garg R, Gulia AK, et al: Dyke-Davidoff-Masson Syndrome- a rare cause of refractory epilepsy. Iran J Psychiatry. 2014; 9(1): 42-4. PubMed Abstract | Free Full Text

86. Park KI, Chung JM, Kim JY: Dyke-Davidoff-Masson Syndrome: cases of two brothers and literature review. J Epilepsy Res. 2014; 4(1): 24-7. PubMed Abstract | Publisher Full Text | Free Full Text

87. Kumar NV, Gugapriya TS, Guru AT, et al:: Dyke-Davidoff-Masson syndrome. Int J Appl Basic Med Res. 2016; 6(1): 57-59. PubMed Abstract | Publisher Full Text | Free Full Text

88. Ayas ZÖ, Asil K, Öcal R: The clinico-radiological spectrum of Dyke-DavidoffMasson syndrome in adults. Neurol Sci. 2017; 38(10): 1823-8. PubMed Abstract | Publisher Full Text

89. Sarangi P, Mangaraj PD, Mohanty J: Dyke-Davidoff-Masson Syndrome (DDMS): A rare preventable cause of refractory epilepsy. American Journal of Diagnostic Imaging. 2017; 1(1): 28 Publisher Full Text

90. Li Y, Zhang T, Li B, et al.: A potential cause of adolescent onset DykeDavidoff-Masson syndrome: A case report. Medicine (Baltimore). 2019; 98(51): e18075.

PubMed Abstract | Publisher Full Text | Free Full Text

91. https://www.drugbank.ca/drugs/DB06218/. accessed on August 252020 


\section{Open Peer Review}

\section{Current Peer Review Status:}

\section{Version 1}

Reviewer Report 21 June 2022

https://doi.org/10.5256/f1000research.30937.r134971

(C) 2022 Shahid R. This is an open access peer review report distributed under the terms of the Creative Commons Attribution License, which permits unrestricted use, distribution, and reproduction in any medium, provided the original work is properly cited.

\section{Rizwana Shahid}

Section of Neurology, College of Medicine, Imam Abdulrahman Bin Faisal University, Dammam, Saudi Arabia

It is an interesting case, highlighting a rare disease with the co-occurrence of the current pandemic. As we are aware, any infection can precipitate status epilepticus in epileptic patients, but with the emergence of the new COVID-19 virus, this report gives the reader good insight.

In this patient, the reason for status epilepticus is multifactorial rather than being secondary to only DDMS/COVID-19 infection, and the authors have addressed this issue in their discussion.

There is one issue that needs to be addressed:

The patient was chronic epileptic, as per the authors, and was on many AED but there is no imaging done before. Can you explain why the patient wasn't worked up before?

Is the background of the case's history and progression described in sufficient detail? Yes

Are enough details provided of any physical examination and diagnostic tests, treatment given and outcomes?

Partly

Is sufficient discussion included of the importance of the findings and their relevance to future understanding of disease processes, diagnosis or treatment?

Yes

Is the case presented with sufficient detail to be useful for other practitioners? Yes

Competing Interests: No competing interests were disclosed. 
I confirm that I have read this submission and believe that I have an appropriate level of expertise to confirm that it is of an acceptable scientific standard.

Reviewer Report 29 January 2021

https://doi.org/10.5256/f1000research.30937.r76973

(C) 2021 Noormahomed E. This is an open access peer review report distributed under the terms of the Creative Commons Attribution License, which permits unrestricted use, distribution, and reproduction in any medium, provided the original work is properly cited.

\section{Emilia Virginia Noormahomed}

Department of Microbiology, Universidade Eduardo Mondlane (UEM), Maputo, Mozambique

This is an interesting and unique case report presentation documenting a COVID-19 and status epilepticus in Dyke-Davidoff-Masson syndrome, its management and outcomes. It also discusses and highlights some precautions to be considered when treating patients in SE and COVID-19. The infection by SARS-COV-2 is a very recent disease which possesses many challenges in terms of diagnosis and clinical management of its less common clinical presentation. This case report and review of the literatures provide scientific information that will enrich the few existing data, thus contributing to better understand the disease and associated co-morbidities, especially in case of associated neurological diseases.

Further, this case report is of potential importance to a global audience. My suggestions for further improvement are as follows:

1. Make corrections to language and grammar in the manuscript.

2. Spell out some acronyms the first time they write it.

Is the background of the case's history and progression described in sufficient detail? Yes

Are enough details provided of any physical examination and diagnostic tests, treatment given and outcomes?

Yes

Is sufficient discussion included of the importance of the findings and their relevance to future understanding of disease processes, diagnosis or treatment?

Yes

Is the case presented with sufficient detail to be useful for other practitioners? Yes

Competing Interests: No competing interests were disclosed. 
Reviewer Expertise: Infectious diseases and health professionals education

I confirm that I have read this submission and believe that I have an appropriate level of expertise to confirm that it is of an acceptable scientific standard.

Author Response 29 Jan 2021

Humberto Foyaca-Sibat, Walter Sisulu University/ Nelson Mandela Academic Hospital, Mthatha, South Africa

Dear Prof Noormahoomed

Thanks a lot for your review and constructive suggestions. We will correct by what you suggested.

Again, thanks for your kind attention and professionalism

Regards

Dr Foyaca

Competing Interests: No competing interests were disclosed.

The benefits of publishing with F1000Research:

- Your article is published within days, with no editorial bias

- You can publish traditional articles, null/negative results, case reports, data notes and more

- The peer review process is transparent and collaborative

- Your article is indexed in PubMed after passing peer review

- Dedicated customer support at every stage

For pre-submission enquiries, contact research@f1000.com 